\title{
EVALUATION OF THE STRATEGIES COPING WITH CONSUMERS' GUILT AND SHAME IN IMPULSE BUYING: A STUDY ON UNIVERSITY STUDENTS
}

\author{
*Hatice AYDIN \\ ** Sevtap ÜNAL \\ * Muş Alparslan University,Turkey \\ ** Atatürk University, Erzurum
}

\begin{abstract}
Guilt and shame are negative self-consciousness emotions which occur after consumer buying behavior. Consumers benefit from the planning to make up for the monetary lost and planning to reduce impulse buying strategies to coping with guilt. They benefit from mental disengagement, resignation, blame others, mental undoing, rationalization and seeking social support coping with shame. Guilt, shame and coping strategy influence consumers' repurchase intention. The aims of this study is to determine whether there has been a sense of guilt and shame after impulse buying and coping strategies taken into account of these emotions. In addition, it is aim to determine impact of these emotions and coping strategies on the repurchase intention. In this direction, a survey was carried out for the students at Istanbul and Marmara Universities. According to the survey results; impulse buying effects guilt and shame emotions, these emotions effect coping strategies and repurchase intention. It has been determined that guilt effects planning to make up for the monetary lost and planning to reduce impulse buying; shame effects mental disengagement, resignation, blame others, mental undoing, rationalization and seeking social support strategies. Also it has been determined that coping strategies except mental undoing effect repurchase intention.
\end{abstract}

Keywords: Impulse Buying, Consumer Guilt, Consumer Shame, Coping With Strategies, Repurchase Intention.

\section{INTRODUCTION}

Guilt and shame are negative consciousness feelings that every person has in variable degrees and that affect their attitudes and behaviors. It is considered that they cannot be explained precisely in the marketing literature though they are in the center of our actions and play a very important role in making sense of our thoughts and behaviors. There are many factors influential on their emergence. Impulse buying is one of the most important factors influential in the emergence of these feelings. Impulse buying is a buying behavior that is observed in a consumer with a strong impulse to own a particular product. Consumers cannot control the situation while they make such purchases and do not pay attention to their results. Though such feelings as excitement and pleasure are felt for a while as a result of impulse buying, these feelings are replaced with negative ones such as regret, ambivalence, and the concern about being judged by the society. Consumers pay attention not to make such purchases in the future so as not to experience such feelings again. Thus, these feelings may affect the buying behavior negatively one more time. Consumers benefit from coping strategies in order to alleviate the negative effects of these feelings. They benefit from the planning to make up for monetary loss and to reduce impulse buying for coping with guilt and from such strategies as mental disengagement, blaming others, resignation, mental undoing, rationalization, and seeking social support for coping with shame. The strategies for coping with guilt decrease the intentions to buy again while the strategies to cope with shame have a different effect. The consumers seeking social support take into account the suggestions of others, try to soothe themselves psychologically, and may repurchase in the future as they justify their buying behaviors. As for the consumers benefiting from such strategies as mental disengagement, resignation, and blaming others, they do not repeat such purchases in the future.

As these feelings which regulate the thoughts and behaviors of consumers have important effects on the process of making a decision to buy, it is aimed in the present study to determine strategies to cope with the 
feelings of guilt and shame in impulse buying cases. With this purpose, a survey was administered to students studying in Istanbul and Marmara universities. The study consists of 3 parts. In the first part, theoretical information and the research hypotheses regarding negative consciousness feelings and coping strategies are handled; in the second part, implementation process is explained; and lastly, in the third part, the results and recommendations regarding the research are given place

\section{THEORETICAL FRAMEWORK AND HYPOTHESES}

\section{Negative Self Conscious Emotions}

Emotions have some reactions and various psychological parts like congnitive feelings (Aren and Aydemir, 2014; 49). Negative consciousness emotions are cognitive and about the personality of an individual (Pounders, 2011). These feelings fall into 2 groups: 1) negative feelings such as shame, guilt, and reprimand and 2) positive feelings like pride (Tangney et al., 2007; 347). The negative self-consciousness feelings that are confused with one another and should be focused on are guilt and shame. It is considered that they are very different from one another in terms of their reflections and the coping strategies though they are from the same family (Pounder, 2011). Guilt is felt with the effect of the regret that a consumer has due to his buying or not buying a particular product (Tracy et al, 2007; 6). In other words, it is felt when a person does not buy something that he/she should buy or when he/she buys something that he/she should not buy. As for shame, it is felt when people think that they have flaws about themselves or against some people (Tangney and Dearing, 2002; 18). These feelings emerge when people watch commercial news, spend time in stores, talk with a salesperson, or evaluate the characteristics of a store or a product or service (i.e. in every area of a consumer's life) (Edell and Burke, 1987; 421). Thus, they have an effect on thoughts and actions and help consumers decide and determine their priorities (Stevens, 1998; 23).

\section{Coping with Strategies}

Coping strategies are efforts used in reducing the severity of feelings that affect the life negatively and of regret (Zeelenberg and Pieters, 2007; 15). They are very influential on decision-making processes. They are considered to be a part of motivation as well as decision-making and the following strategies are employed regarding impulse buying (Yi and Baumgartner, 2011): The planning to reduce Impulse Buying: It aims to reduce the frequency and quantity of impulse buyings. It involves going shopping with a shopping list, having money only enough to buy what is needed, spending according to a budget, and leaving a place when a consumer feels that he/she will spend money unnecessarily. The planning to make up for Monetary Loss: This plan is made in order to avoid monetary loss arising from impulse buying. It involves making up for the money spent in shopping, reducing expenditures, earning side incomes, allotting the budget to make up for the losses, and not going out to avoid spending money. It is indicated that the planning to make up for monetary loss is a short-term solution and eliminates negative feelings only for a short time (Tam and Dholakia, 2008; 27). Mental Disengagement: It involves consumers' looking for such solutions as lying about their purchases and watching TV more and distracting themselves when they believe that they cannot control their negative feelings. Resignation: Resignation means a consumer accepts the truth that he/she cannot cope with impulse buying (Yi, 2012; 400). Blaming Others: It is a consumer's attributing the reasons for his/her purchases and feelings to other people and blaming them. Mental Undoing: It is about whitewashing a weak situation by making an effort in another area and disregarding the buying behavior. Rationalization: Rationalization means that consumers see the failure they experience as a result of their inconsistent attitudes and behaviors and look for excuses. These excuses are that they believe they deserve what they buy; their purchases are the worth of their money; and they can make up for that loss (Yi and Baumgartner, 2011; 460). Seeking Social Support: It is the material and moral support provided to make a positive effect by keeping an individual away from problems (Cohen and Wills, 1985; 313).

The planning to reduce impulse buying and the planning to make up for monetary loss are among "problemfocused" strategies while mental disengagement, resignation, and blaming others are among "disengagement" strategies, and social support, rationalization, and mental undoing are among "emotionfocused” strategies (Yi and Baumgartner, 2011; 461). However, disengagement strategies can be handled under emotion-focused strategies, as well (Lazarus and Folkman, 1984) because they do not involve any direct effort to change negative emotions as is the case in emotion-focused strategies but include behaviors such as calming down before negative feelings (Duhachek, 2004; 38). Emotions and coping strategies are one 
Journal of Global Strategic Management | V. 9 | N. 2 | 2015-December | isma.info | 119-133 | DOI: 10.20460/JGSM.2015915578

of the most important subjects that should be handled in terms of consumer behavior since consumers are affected from their emotions and the coping strategies while making an evaluation after buying something and in making a decision to buy again (Ladhari et al, 2008; Ha and Lennon, 2010). Recently, the number of studies focusing on coping strategies and emotions has increased in the marketing literature.

Dedeoğlu and Kazançoğlu carried out a study in 2011 to find out measures of guilt. According to the results, it was determined that guilt had 5 measures: hesitation, sadness, reluctance to spend money, regret, and blaming oneself. Pounders researched the similarities and differences between guilt and shame in the study she conducted in 2011. The results indicated that two feelings were different. Yi and Kanetkar (2011), Lozınskı (2011), Jun and Yeo (2012) researched the relationship between guilt, shame, anger, and fear that are felt as a result of gambling loss, dieting and buying cell phones and coping strategies. According to the results, it was found out that the intensity and severity of gambling were more related to shame while the consumers who felt ashamed because of gambling loss and dieting chose the disengagement strategy among the coping strategies. It was also determined that the emotions felt after buying cell phones were mostly fear and anger, and angry consumers preferred disengagement and seeking social support while the ones having fear benefitted only from the strategy of seeking social support. Yi and Baumgartner researched how to cope with guilt and shame in the study they carried out in 2011. The results demonstrated that mental undoing and the planning to reduce impulse buying and to make up for monetary loss were used to cope with guilt while the strategies of mental disengagement, resignation and blaming others were chosen to cope with shame. Yi (2012) and Lu et al. (2012) studied the relationships of compulsive buying, coping strategies, guilt shame proneness, dissatisfaction, negative feelings, and the intention to repurchase. According to the results, a positive relationship was found between coping strategies and shame; a negative relationship was found between guilt and the strategies other than mental disengagement; and a positive relationship was found between compulsive buying and disengagement while it was determined that compulsive buying was mostly related to shame. It was also determined that the effect of dissatisfaction on negative feelings; the effect of negative feelings on coping strategies; and the effect of psychological withdrawal and social support on the intention to repurchase were significant. Dedeoğlu and Kazançoğlu (2012) studied the effects of regret, norm violations, self-control failure, and hedonic desires on guilt. The results indicate that regret, self-control failure, and hedonic consumption are the most influential factors on guilt.

As it is understood from the literature, the studies generally touch on only one dimension of feelings such as consumer guilt (Dedeoğlu, Kazançoğlu, 2010, 2012). The coping strategies are about the general life on the whole and are not suitable for the concept of impulse buying. For this reason, the present study gives place to the strategies of the planning to reduce impulse buying and the planning to make up for monetary loss which take into account the concept of impulse buying. Also, feelings are handled in terms of guilt and shame which are based on important incidents such as impulse buying rather than the proneness to guilt and shame appearing in the psychology literature.

\section{Development of Hypotheses}

Impulse buyings are the purchases which are made by consumers for reasons such as seeking excitement, but produce totally opposite results. Consumers realize that they spend too much money and buy unnecessary things after such purchases and regret and feel an intensive guilt and shame (Maclnnis and Patrick, 2006; 227).

\section{H1a: Impulse buying positively affects consumer's guilt emotion.}

\section{H1b: Impulse buying positively affects consumer's shame emotion.}

Negative feelings come out as a result of significant incidents and affect the buying behavior (Zaltman, 1997; Zeelenberg and Pieters, 2004). In this regard, guilt and shame have an effect on intentions to buy again (Mattila and Ro, 2008; 103).

H2a: Consumer's guilt emotion negatively affects repurchase intention.

H2b: Consumer's shame emotion negatively affects repurchase intention.

Repurchase intentions generally refer to the likelihood of using a brand again in the future (Şahin et al, 2012; 11194). According to Lazarus (1991), negative feelings affect the intention to repurchase and show the need for coping strategies. According to Frijda, Kuipers and Tershure (1989), different negative feelings require 
different strategies. As guilt requires the evaluation of the relevant behavior, the planning to reduce impulse buying and the planning to make up for monetary loss are used in coping with this feeling (Yi and Baumgartner, 2011). The consumers the buying behaviors of whom are not approved by the people in their environment feel ashamed and benefit from coping strategies to reduce the devastating results. They mostly display dysfunctional behaviors such as defending themselves, disengagement, and resignation. They also benefit from more passive or emotion-focused strategies such as seeking social support, mental undoing, and rationalization (Yi and Baumgartner, 2004; Yi and Baumgarner, 2011). Thus, it is claimed that there is a positive relationship between the strategies of mental undoing, seeking social support, and rationalization and the feeling of shame since the strategies are emotion-focused strategies in general (Lazarus and Folkman, 1984; Strutton and Lumpkin, 1994; Yi, 2012; Yi and Kanetkar, 2012).

H3a: Guilt emotion positively affects planning to reduce impulse buying strategy.

H3b: Guilt emotion positively affects planning to make up monetary lost strategy.

H4a: Shame emotion positively affects mental disengagement strategy.

$H 4 b$ : Shame emotion positively affects resignation strategy.

H4c: Shame emotion positively affects blame others strategy.

H4d: Shame emotion positively affects mental undoing strategy.

H4e: Shame emotion positively social support strategy.

H4f: Shame emotion positively affects rationalisation strategy.

Consumers' strategies to cope with their feelings after a purchase affect their future behaviors. Consumers begin to have more self-control regarding the purchases they will make in the future. When they feel guilty, they avoid impulse buying and monetary loss. Thus, their future purchases decrease (Dedeoğlu and Kazançoğlu, 2012). Emotion-focused coping is an effort to distract the attention from negative feelings (Menon and Dube, 2004; 230). Mental disengagement, resignation, and blaming others lead to a decrease in behaviors repeating the purchase as they involve getting rid of shame and giving up useless actions (Lu et al. 2012). As for social support and rationalization, they make a positive effect on buying ( $\mathrm{Lu}$ et al, 2012; Venkatesh et al. 2003; 447). Positive effect comes out because the strategies of social support and rationalization balance the effect of shame on the intention to repurchase. Also, consumers resorting to these strategies think that they really need what they buy. They reevaluate the situation and come to more positive conclusions in comparison to their previous situations.

H5a: Planning to reduce impulse buying strategy negatively affects repurchase intention.

H5b: Planning to make up monetary lost strategy negatively affects repurchase intention.

H6a: Mental disengagement strategy negatively affects repurchase intention.

H6b: Resignation strategy negatively affects repurchase intention.

H6c: Blame others strategy negatively affects repurchase intention.

H6d: Mental undoing strategy positively affects repurchase intention.

H6e: Social support strategy positively affects repurchase intention.

H6f: Rationalisation strategy positively affects repurchase intention

Research models had shown as in figure 1 and figure 2. 


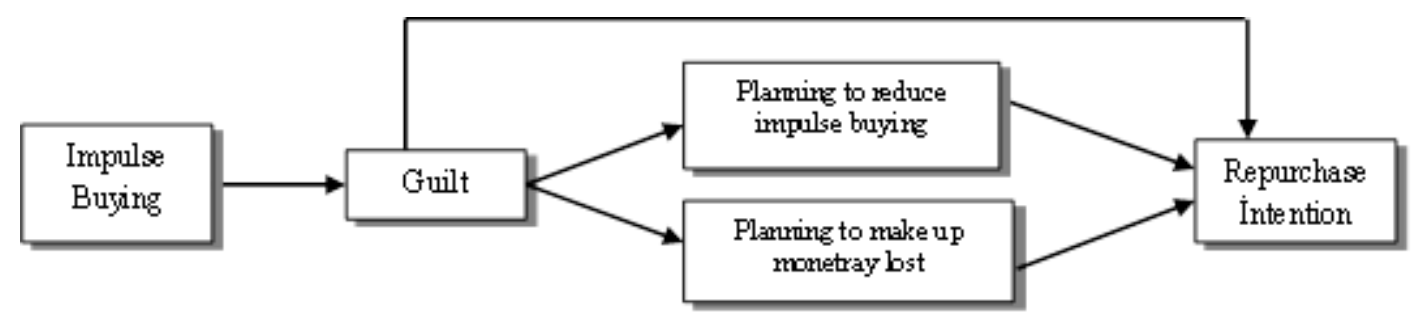

Figure 1. Model of Coping with Consumer Guilt

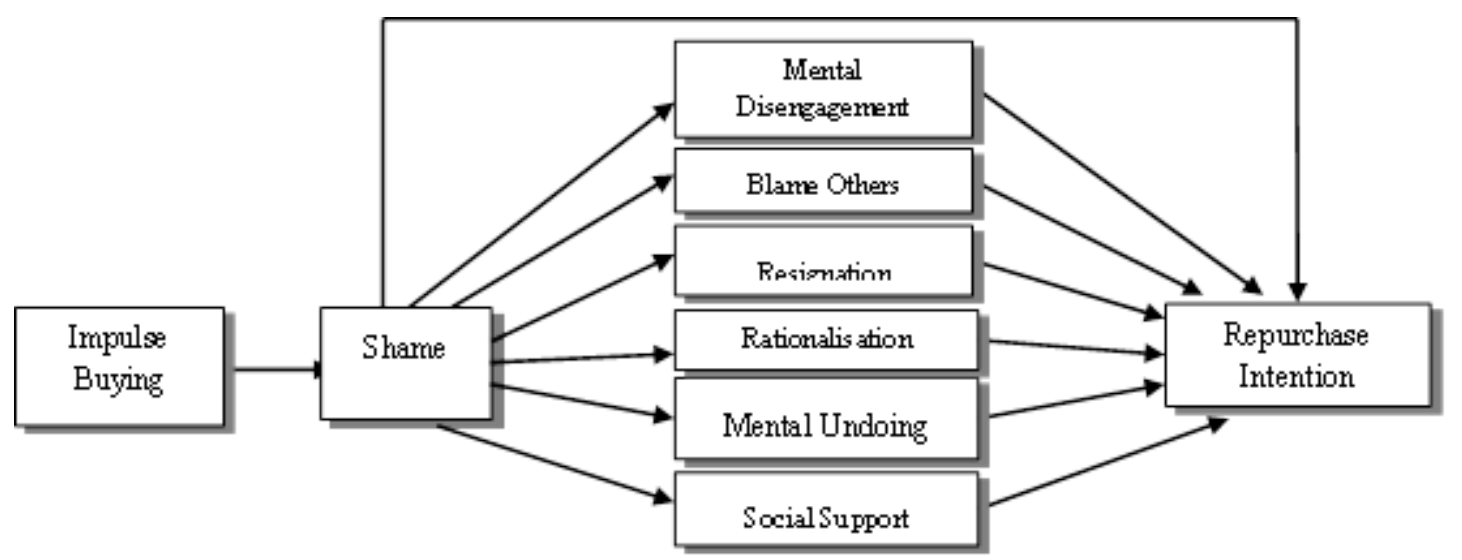

Figure 2. Model of Coping with Consumer Shame

\section{METHODOLOGY}

The aim of the study is to determine the strategies which are effective in coping with guilt and shame. The sub-aims determined within the scope of this main aim are to determine the relationship between impulse buying and guilt and shame, to examine the role of guilt, shame, and the employed strategies on the intention to repurchase, and to find out which feeling is experienced the most after impulse buyings and which feeling has the most effect on the intention to repurchase. The study was carried out with university students studying in Istanbul. It was conducted with the students of Marmara University and Istanbul University. Convenience sampling method was used. The sample size was determined as $n=500$ with a confidence interval of $95 \%$ and an error margin of $5 \%$. After elimination of the survey, 455 survey were taken into account. The data were collected through face to face survey. The survey consisted of 2 groups of questions. The first group measured impulse buying, guilt, shame, coping strategies, and the intention to repurchase while the second group measured demographic characteristics. Impulse buyings were measured using the scale developed by Rook and Fisher (1995); shame and guilt with the scale developed by Marschall et al. (1994) and Marschall (1996); the intention to repurchase with the scale developed by Parasuraman (2005) and Pavlou and Fygenson (2006); and the coping strategies with the scale developed by Yi and Baumgartner (2011). The variables were prepared in a 5-point Likert scale. The data were analyzed using SPSS 20,0 and LISREL 8.7 statistical. They were subjected to descriptive statistics, confirmatory factor analysis, structural equation modeling.

\section{Demographic Characteristics of Respondent}

$39.6 \%$ of the participants were male, and $60.4 \%$ were female. The mode of their ages was 19 , while the median was $20.96 .7 \%$ were single, while $3.3 \%$ were married. $23.5 \%$ had an income under TL $500 ; 38.7 \%$ between TL 501 and 750; 26.6\% between TL 751 and 1000; 4.6\% between TL 1001 and 1250; and 6.6\% had an income higher than TL 1250. 


\section{Test of Research Model}

The testing of the research models was carried out in 6 stages. The 1st Stage: The scales consisting of 75 variables were subject to reliability analysis, and it was seen that the reliability results of the scales were good, and no variable was left out. The 2nd Stage: The model of guilt was tested in the first place. Impulse buying, the feeling of guilt, the intention to repurchase, the planning to reduce impulse buying, and the planning to make up for monetary loss variables within the model of guilt were tested through confirmatory factor analysis. The 3rd Stage: A structural equation analysis was performed to test the model of guilt. At this stage, the effects of impulse buying on guilt and those of guilt on impulse buying and the planning to make up for monetary loss were studied. Also, the effects of the feeling of guilt and the related coping strategies on the intention to repurchase were examined. The 4th Stage: The model of shame was tested. The variables of impulse buying, the feeling of shame, the intention to repurchase, mental disengagement, resignation, blaming others, seeking social support, mental undoing, and rationalization within the model of shame were tested through confirmatory factor analysis. The 5th Stage: A structural equation analysis was conducted to test the model of shame. At this stage, the effects of impulse buying on shame and the effects of shame on mental disengagement, resignation, blaming others, seeking social support, mental undoing, and rationalization strategies were handled. The effects of shame and the relevant coping strategies on the intention to repurchase were studied. The 6th Stage: The models of guilt and shame were compared in terms of input and output variables.

The goodness of fit indices (GDI) of the measurement models composed of 75 questions and 12 variables demonstrated that the measurement models had a poor fit. The variables which showed negative variance, those whose standard coefficients were very close to 1.0; and those which yielded very substantial standard errors were checked, and the unsuitable variables were removed (Hair et al, 1998). The models turned out to be within acceptance boundaries as a result of the elimination of 3 variables from IC, 1 from PR, 1 one ICP, 2 from UT, 6 from ZK, 4 from VZ, 2 from MT, 2 from ZT, and 3 from SOS in line with the modifications suggested. The fit values in before and after the modifications are given in Table 1 . The standard values of the variables remaining in the models after the suggested modifications, $R 2$, error variances, $t$ values, construct reliability values, variance explanation rates, and Cronbach's Alpha coefficients are given in Table 2. It is seen that the standardized regression values were significant at 0.01 significance level. That the construct reliability value of the factors was higher than 0.70 and the variance explanation rates were higher than 0.50 demonstrated that the scales were reliable and valid.

The predictions on direct and indirect effects of the variables in the models and t values are given in Table 3. As mental undoing did not have a significant effect on the intention to repurchase, H6d hypothesis was rejected while H1a, H1b, H2a, H2b, H3a, H3b, H4a, H4b, H4c, H4d, H4e, H4f, H5a, H5b, H6a, H6b, H6c, H6e, and H6f hypotheses were accepted as all other effects were significant. As it is seen in Figure 3, while impulse buyings explain guilt by $0.43 \%$; guilt explains the planning to make up for monetary loss by $0.18 \%$ and the planning to reduce impulse buying by $0.28 \%$. Furthermore; guilt, the planning to make up for monetary loss, and the planning to reduce impulse buying explain the intention to repurchase by $0.47 \%$. In Figure 4 , it is seen that impulse buying explains shame by $0.26 \%$ while shame explains mental disengagement by $0.53 \%$, resignation by $0.61 \%$, blaming others by $0.19 \%$, seeking social support by $0.74 \%$, mental undoing by $0.11 \%$, and rationalization by $0.015 \%$. Also, the feeling of shame explains the intention to repurchase by $0.61 \%$. 
Journal of Global Strategic Management | V. 9 | N. 2 | 2015-December | isma.info | 119-133 | DOI: 10.20460/JGSM.2015915578

Table 1. Goodness of Fit Statistics of Consumer Guilt and Shame Models

\begin{tabular}{|c|c|c|c|c|c|}
\hline \multirow[b]{2}{*}{$\begin{array}{l}\text { Goodness- } \\
\text { of-fit index }\end{array}$} & \multicolumn{2}{|c|}{ Consumer Guilt Model Tests } & \multirow[b]{2}{*}{ Acceptable fit } & \multicolumn{2}{|c|}{ Consumer Shame Model Tests } \\
\hline & $\begin{array}{l}\text { Before } \\
\text { Modification }\end{array}$ & $\begin{array}{l}\text { After } \\
\text { Modification }\end{array}$ & & $\begin{array}{l}\text { Before } \\
\text { Modification }\end{array}$ & $\begin{array}{l}\text { After } \\
\text { Modification }\end{array}$ \\
\hline \multicolumn{6}{|c|}{ Absolute fit value } \\
\hline$X^{2}$ & 631.90 & 524.55 & & 1252.12 & 818.61 \\
\hline $\begin{array}{l}\text { Degree of } \\
\text { Freedom (df) }\end{array}$ & 246 & 224 & & 580 & 420 \\
\hline$\left(X^{2} / d f\right)$ & 2.56 & 2.34 & $1-5$ & 2.15 & 1.94 \\
\hline GFI & 0.90 & 0.91 & $0.90 \leq \mathrm{GFI} \leq 0.95$ & 0.87 & 0.90 \\
\hline AGFI & 0.87 & 0.89 & $0.85 \leq \mathrm{AGFI} \leq 0.90$ & 0.85 & 0.88 \\
\hline SRMR & 0.063 & 0.060 & $0.05 \leq \mathrm{SRMR} \leq 0.10$ & 0.072 & 0.066 \\
\hline RMSEA & 0.059 & 0.054 & $0.05 \leq \mathrm{RMSEA} \leq 0.08$ & 0.051 & 0.046 \\
\hline CFI & 0.94 & 0.95 & $0.95 \leq \mathrm{CFI} \leq 0.97$ & 0.94 & 0.96 \\
\hline$N N F I=T L I$ & 0.94 & 0.95 & $0.95 \leq \mathrm{NNFI} \leq 0.97$ & 0.94 & 0.95 \\
\hline NFI & 0.91 & 0.92 & $0.90 \leq \mathrm{NFI} \leq 0.95$ & 0.90 & 0.92 \\
\hline
\end{tabular}


Journal of Global Strategic Management | V. 9 | N. 2 | 2015-December | isma.info | 119-133 | DOI: 10.20460/JGSM.2015915578

Table 2. Research Variables in Guilt and Shame Models after Modification

\begin{tabular}{|c|c|c|c|c|c|c|c|}
\hline \multicolumn{8}{|c|}{ Research Variables in Consumer Guilt Model after Modification } \\
\hline Observed Variable & $\dot{\omega}$ & $\approx$ & 窗 & 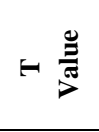 & 总: & 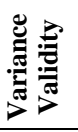 & 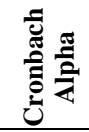 \\
\hline Impulse Buying = IC & 0.86 & 0.74 & 0.51 & 12.23 & 0.92 & 0.68 & 0.94 \\
\hline I often buy things spontaneously. & 0.83 & 0.69 & 0.66 & 12.83 & & & \\
\hline "Just do it" describes the way I buy things. . & 0.91 & 0.82 & 0.35 & 10.42 & & & \\
\hline I often buy things without thinking. . & 0.83 & 0.68 & 0.66 & 12.91 & & & \\
\hline "I see it, I buy it" describes me. & 0.78 & 0.61 & 0.65 & 13.53 & & & \\
\hline I buy things according to how I feel at the moment. & 0.76 & 0.58 & 0.66 & 13.70 & & & \\
\hline Sometimes I feel like buying things on the spur-of-the-moment. & 0.86 & 0.74 & 0.51 & 12.23 & & & \\
\hline Guilt Emotion= SUC & & & & & 0.88 & 0.60 & 0.89 \\
\hline I buy impulsively and then I regret. & 0.77 & 0.59 & 0.50 & 12.67 & & & \\
\hline $\begin{array}{l}\text { I feel nervous when I realize that I have bought something that I } \\
\text { do not really like or need. }\end{array}$ & 0.76 & 0.57 & 0.49 & 12.89 & & & \\
\hline I think impulse buying is not right. & 0.85 & 0.72 & 0.37 & 10.90 & & & \\
\hline $\begin{array}{l}\text { I feel sad and apologize from my family and other people to } \\
\text { whom I am responsible for this insensible behavior. }\end{array}$ & 0.73 & 0.53 & 0.69 & 13.22 & & & \\
\hline I feel bad after shopping. & 0.77 & 0.60 & 0.53 & 12.64 & & & \\
\hline Repurchase Intention= NY & & & & & 0.87 & 0.69 & 0.88 \\
\hline I buy things that I have already bought without thinking. & 0.85 & 0.72 & 0.45 & 9.95 & & & \\
\hline $\begin{array}{l}\text { Most probably, I will buy things that I have already bought again } \\
\text { in the future. }\end{array}$ & 0.87 & 0.76 & 0.39 & 8.59 & & & \\
\hline I have an intention to purchase without thinking again. & 0.78 & 0.62 & 0.68 & 11.93 & & & \\
\hline Planning to Make up Monetray Lost $=$ PR & & & & & 0.84 & 0.57 & 0.85 \\
\hline I try to make up for the money I spend and earn side incomes. & 0.79 & 0.62 & 0.61 & 10.91 & & & \\
\hline $\begin{array}{l}\text { I consider that I exceed my daily/weekly/monthly budget and try } \\
\text { not to go out or spend money. }\end{array}$ & 0.66 & 0.44 & 0.84 & 13.22 & & & \\
\hline I try to earn the money back by doing an extra job. & 0.69 & 0.47 & 0.87 & 12.93 & & & \\
\hline I plan my budget to make up for the loss that I cause. & 0.87 & 0.75 & 0.40 & 7.82 & & & \\
\hline Planning to Reduce Impulse Buying= ICP & & & & & 0.85 & 0.54 & 0.87 \\
\hline $\begin{array}{l}\text { I spend according to my budget and try to avoid buying things } \\
\text { which cause me to spend money unnecessarily. }\end{array}$ & 0.76 & 0.58 & 0.59 & 11.93 & & & \\
\hline I make shopping plan in order not to repeat the same attitude. & 0.72 & 0.52 & 0.68 & 12.66 & & & \\
\hline $\begin{array}{l}\text { I take into account the opinions that help me reduce the number of } \\
\text { purchases I make. }\end{array}$ & 0.83 & 0.69 & 0.40 & 9.99 & & & \\
\hline $\begin{array}{l}\text { I try to reduce instant buying by making a list of needs before the } \\
\text { next shopping and avoiding buying things that are not on the list. }\end{array}$ & 0.73 & 0.53 & 0.74 & 12.56 & & & \\
\hline $\begin{array}{l}\text { When I feel that I will buy something without thinking, I just } \\
\text { walk away from where I am. }\end{array}$ & 0.63 & 0.39 & 0.97 & 13.61 & & & \\
\hline \multicolumn{8}{|c|}{ Research Variables in Consumer Shame Model after Modification } \\
\hline Impulse Buying = IC & & & & & 0.92 & 0.73 & 0.93 \\
\hline I often buy things spontaneously. & 0.85 & 0.73 & 0.53 & 11.61 & & & \\
\hline "Just do it" describes the way I buy things. . & 0.85 & 0.72 & 0.60 & 11.83 & & & \\
\hline I often buy things without thinking. & 0.91 & 0.83 & 0.33 & 8.80 & & & \\
\hline "I see it, I buy it" describes me. & 0.82 & 0.67 & 0.69 & 12.53 & & & \\
\hline Shame Emotion = UT & & & & & 0.85 & 0.66 & 0.92 \\
\hline $\begin{array}{l}\text { I beware of the people to whom I am responsible and cannot look } \\
\text { at their faces thinking that my impulsive shopping would not be } \\
\text { welcome by them. }\end{array}$ & 0.81 & 0.66 & 0.79 & 12.40 & & & \\
\hline Thinking that my impulsive spending would be considered a & 0.81 & 0.65 & 0.78 & 12.51 & & & \\
\hline
\end{tabular}


Journal of Global Strategic Management | V. 9 | N. 2 | 2015-December | isma.info | 119-133 | DOI: 10.20460/JGSM.2015915578

\begin{tabular}{|c|c|c|c|c|c|c|c|}
\hline \multicolumn{5}{|l|}{$\begin{array}{l}\text { weakness, I feel that I am incapable0 before the people to whom I } \\
\text { am responsible. }\end{array}$} & \multirow[b]{3}{*}{0.87} & \multirow[b]{3}{*}{0.69} & \multirow[b]{3}{*}{0.88} \\
\hline \multirow{2}{*}{$\begin{array}{l}\text { I see myself as a weak person after buying something. } \\
\text { Repurchase Intention = NY }\end{array}$} & 0.83 & 0.68 & 0.60 & 12.08 & & & \\
\hline & & & & & & & \\
\hline I buy things that I have already bought without thinking. & 0.85 & 0.72 & 0.45 & 10.30 & & & \\
\hline $\begin{array}{l}\text { Most probably, I will buy things that I have already bought again } \\
\text { in the future. }\end{array}$ & 0.87 & 0.77 & 0.38 & 9.00 & & & \\
\hline I have an intention to purchase without thinking again. & 0.78 & 0.61 & 0.69 & 12.22 & & & \\
\hline \multicolumn{5}{|l|}{ Resignation $=\mathrm{VZ}$} & 0.89 & 0.74 & 0.92 \\
\hline $\begin{array}{l}\text { If I do not use a product that I have bought on impulse, I give it as } \\
\text { a gift. }\end{array}$ & 0.88 & 0.80 & 0.44 & 10.00 & & & \\
\hline $\begin{array}{l}\text { I try to exchange a product that I have bought on impulse with } \\
\text { something that I really need. }\end{array}$ & 0.90 & 0.67 & 0.36 & 8.87 & & & \\
\hline $\begin{array}{l}\text { I try to give a product that I have bought on impulse back to the } \\
\text { store. }\end{array}$ & 0.82 & 0.55 & 0.65 & 12.11 & & & \\
\hline \multicolumn{5}{|l|}{ Mental Disengagement $=\mathrm{ZK}$} & 0.88 & 0.66 & 0.92 \\
\hline I lie to the people around me about the purchases I make. & 0.77 & 0.59 & 0.82 & 12.81 & & & \\
\hline I do not give up my habits such as smoking and drinking alcohol. & 0.87 & 0.75 & 0.44 & 10.22 & & & \\
\hline $\begin{array}{l}\text { I try not to show my feelings to other people after I buy } \\
\text { something. }\end{array}$ & 0.84 & 0.70 & 0.58 & 11.36 & & & \\
\hline I do not tell anything about a purchase that I make to anyone. & 0.80 & 0.63 & 0.68 & 12.34 & & & \\
\hline \multicolumn{5}{|l|}{ Blame Others $=$ BS } & 0.86 & 0,68 & 0,87 \\
\hline $\begin{array}{l}\text { I blame the person who is with me during the shopping about my } \\
\text { purchases. }\end{array}$ & 0.71 & 0.50 & 0.77 & 13.16 & & & \\
\hline I blame the people who cause me to buy things without thinking. & 0.92 & 0.84 & 0.23 & 5.33 & & & \\
\hline I blame the salesperson who helps me during shopping. & 0.85 & 0.72 & 0.41 & 9.18 & & & \\
\hline \multicolumn{5}{|l|}{ Rationalisation = MT } & 0.86 & 0.61 & 0.87 \\
\hline $\begin{array}{l}\text { I make myself believe that I deserve it even if I buy something } \\
\text { without thinking. }\end{array}$ & 0.74 & 0.55 & 0.66 & 12.15 & & & \\
\hline I think I really need what I buy. & 0.82 & 0.67 & 0.50 & 10.26 & & & \\
\hline $\begin{array}{l}\text { I sometimes believe that I have a right to buy something on } \\
\text { impulse. }\end{array}$ & 0.80 & 0.64 & 0.54 & 10.76 & & & \\
\hline $\begin{array}{l}\text { I make myself believe in the idea, "If what I bought was } \\
\text { expensive, the results would be worse." after the purchases I } \\
\text { make. }\end{array}$ & 0.78 & 0.61 & 0.60 & 11.36 & & & \\
\hline \multicolumn{5}{|l|}{ Mental Undoing $=$ ZT } & 0.88 & 0.66 & 0.90 \\
\hline $\begin{array}{l}\text { After I buy something, I think "I wish I could take the time back } \\
\text { and had not spent the money that I spent." }\end{array}$ & 0.80 & 0.65 & 0.71 & 11.78 & & & \\
\hline I try to think as if I had not bought what I bought on impulse. & 0.89 & 0.79 & 0.38 & 8.52 & & & \\
\hline I prefer to forget about the shopping that I have done. & 0.83 & 0.68 & 0.55 & 11.12 & & & \\
\hline $\begin{array}{l}\text { I do not want to believe that I have bought something } \\
\text { impulsively. }\end{array}$ & 0.73 & 0.54 & 0.73 & 13.02 & & & \\
\hline Social Support = SOS & & & & & 0.90 & 0.76 & 0.94 \\
\hline $\begin{array}{l}\text { I share what I feel about the shopping that I have done with other } \\
\text { people. }\end{array}$ & 0.87 & 0.75 & 0.59 & 10.91 & & & \\
\hline I try to get emotional support about the purchases that I make. & 0.88 & 0.77 & 0.49 & 10.43 & & & \\
\hline $\begin{array}{l}\text { I confess to my friends that what I have bought has impressed } \\
\text { me a lot. }\end{array}$ & 0.87 & 0.76 & 0.55 & 10.77 & & & \\
\hline
\end{tabular}


Journal of Global Strategic Management | V. 9 | N. 2 | 2015-December | isma.info | 119-133 | DOI: 10.20460/JGSM.2015915578

Table 3. Estimated Values and Fit Criteria for the Guilt and Shame Models

\begin{tabular}{|c|c|c|c|c|c|c|c|c|}
\hline \multicolumn{9}{|c|}{ Estimated Values and Fit Criteria for the Consumer Guilt Model } \\
\hline \multirow[b]{2}{*}{ Relationships in the model } & \multicolumn{3}{|c|}{$\begin{array}{l}\text { Standardized Impact } \\
\text { Estimations }\end{array}$} & \multirow{2}{*}{ 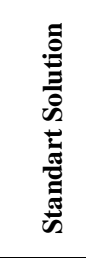 } & \multirow[b]{2}{*}{ 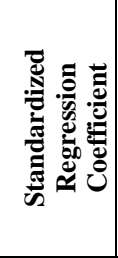 } & \multirow{2}{*}{ 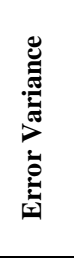 } & \multirow[b]{2}{*}{$-\frac{\stackrel{\text { I }}{>}}{>}$} & \multirow[b]{2}{*}{ 总 } \\
\hline & 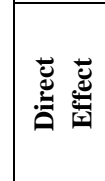 & 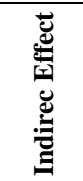 & 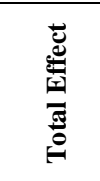 & & & & & \\
\hline Impulse buying-Guilt & 0.65 & - & 0.65 & 0.65 & 0.43 & 0.57 & 12.56 & 0.052 \\
\hline Guilt -Planning to make up monetary lost & 0.43 & - & 0.43 & 0.43 & 0.18 & 0.82 & 7.88 & 0.054 \\
\hline Guilt - Planning to reduce impulse buying & 0.53 & - & 0.53 & 0.53 & 0.28 & 0.72 & 9.47 & 0.055 \\
\hline Guilt - Repurchase Intention & -0.39 & -0.23 & -0.62 & -0.39 & 0.47 & 0.53 & -11.58 & 0.059 \\
\hline $\begin{array}{l}\text { Planning to reduce impulse buying -Repurchase } \\
\text { Intention }\end{array}$ & -0.21 & - & -0.21 & -0.21 & 0.47 & 0.53 & -4.03 & 0.053 \\
\hline $\begin{array}{l}\text { Planning to make up monetary lost - Repurchase } \\
\text { Intention }\end{array}$ & -0.26 & - & -0.26 & -0.26 & 0.47 & 0.52 & -5.31 & 0.050 \\
\hline \multicolumn{9}{|c|}{ Estimated Values and Fit Criteria for the Consumer Shame Model } \\
\hline Impulse buying -Shame & 0.51 & - & 0.51 & 0.51 & 0.26 & 0.74 & 10.09 & 0.051 \\
\hline Shame-Repurchase Intention & -0.41 & -0.28 & -0.69 & -0.41 & 0.61 & 0.39 & -2.73 & 0.15 \\
\hline Shame-Mental Disengagement & 0.73 & - & 0.73 & 0.73 & 0.53 & 0.47 & 13.48 & 0.054 \\
\hline Shame -Resignation & 0.78 & - & 0.78 & 0.78 & 0.61 & 0.39 & 16.14 & 0.049 \\
\hline Shame - Blame Others & 0.44 & - & 0.44 & 0.44 & 0.19 & 0.81 & 8.05 & 0.054 \\
\hline Shame - Mental Undoing & 0.33 & - & 0.33 & 0.33 & 0.11 & 0.89 & 6.43 & 0.052 \\
\hline Shame-Social Support & 0.86 & - & 0.86 & 0.86 & 0.74 & 0.26 & 17.89 & 0.048 \\
\hline Shame-Rationalisation & 0.12 & - & 0.12 & 0.12 & 0.015 & 0.99 & 2.31 & 0.053 \\
\hline Mental Disengagement - Repurchase İntention & -0.41 & - & -0.41 & -0.41 & 0.61 & 0.39 & -6.30 & 0.065 \\
\hline Resignation - Repurchase Intention & -0.14 & - & -0.14 & -0.14 & 0.61 & 0.39 & -2.02 & 0.071 \\
\hline Blame Others - Repurchase Intention & -0.18 & - & -0.18 & -0.20 & 0.61 & 0.39 & -4.00 & 0.044 \\
\hline Mental Undoing - Repurchase Intention & -0.01 & - & 0.01 & 0.01 & 0.61 & 0.39 & 0.31 & 0.040 \\
\hline Social Support - Repurchase Intention & 0.22 & - & 0.22 & 0.22 & 0.61 & 0.39 & 2.28 & 0.098 \\
\hline Rationalisation - Repurchase Intention & 0.10 & - & 0.10 & 0.10 & 0.61 & 0.39 & 2.54 & 0.039 \\
\hline
\end{tabular}

\section{CONCLUSION}

In the present study, the university students' strategies to cope with guilt and shame that they feel after impulse buying were evaluated through different models. According to the results of the first model, impulse buyings had a positive effect on guilt while guilt had a positive effect on reducing impulse buying and making up for monetary loss. The feeling of guilt, impulse buyings, and the strategies to make up for monetary loss had a negative effect on the intention to repurchase. So, the H1a, H2a, H3a, H3b, H5a, and H5b hypotheses were accepted. For coping with guilt, the consumers trying to make up their monetary loss make an effort not to go out and not to spend money or they attempt to make up for the money they spend with side incomes. As for the consumers trying to reduce impulse buying, they make a list of needs for the next shopping, make plans, and walk away from a store where they feel that they will buy something on impulse. These efforts prevent consumers' repeating impulse buying. However, it was seen that the consumers benefitted mostly from the planning to reduce impulse buying in coping with guilt while the planning to make up for monetary loss was effective regarding the intention to repurchase. Students' benefitting more from the planning to reduce impulse buying results from the fact that there are uncontrolled purchases behind guilt and from the idea that the effect of guilt will decrease by reducing the number of such purchases (Rook and Hoch, 1985; 27). As for the planning to make up for monetary loss, it is considered a strategy that is rarely used in coping with guilt because it necessitates a burden such as doing an extra job and gaining a side income and it is a short-term solution (Tam and Dholakia, 2008). The negative effect of 
Journal of Global Strategic Management | V. 9 | N. 2 | 2015-December | isma.info | 119-133 | DOI: 10.20460/JGSM.2015915578 reducing impulse buying on the intention to repurchase is weaker in comparison to that of making up for monetary loss. This is because consumers do not transform the planning to reduce impulse buying to decisive practices. According to the second model, it was determined that impulse buying had a positive effect on shame, and shame had a positive effect on mental disengagement, resignation, blaming others, social support, rationalization, and mental undoing strategies. It was found out that mental disengagement, resignation, and blaming others had a negative effect on repurchase intention while seeking social support and rationalization had a positive effect. It was also determined that mental undoing had no effect on the intention to repurchase. In this regard, the H1b, H2b, H4a, H4b, H4c, H4d, H4e, H4f, H6a, H6b, H6c, H6e, and H6f hypotheses were accepted while the H6d hypothesis was rejected. It was seen that the consumers mostly chose seeking social support, resignation, mental disengagement, and blaming others while they resorted to rationalization and mental undoing the least. The reason for their benefitting from social support the most may be because they think shame is a heavy feeling and its effects can be alleviated by getting help from others. When consumers feel that they cannot do away with the feeling of shame, they try to get away from such feelings physically and mentally. They blame the people who accompany them while shopping and think that they have an influence on their buying something which they normally do not plan to buy. They can cope with their feelings more easily by using the strategy of resignation. The consumers using this strategy make such efforts as to give what they buy as a present to another person, to change it with another product, or return it. As for the reason why the strategies of mental undoing and rationalization are used the least, this is because the negative consciousness feelings in impulse buying not require many more efforts of rationalization. It was determined that the strategies which had the most effect on the intention to repurchase were resignation and social support while the one having the least effect was rationalization. It was also found out that the effect of mental undoing on the intention to repurchase was not significant. The finding that the strategies of seeking social support and mental disengagement had the most effect on the intention to repurchase is consistent with the literature (Beaudry and Pinsonneault, 2010; Lu et al., 2012). The reason why the effect of social support on the intention to repurchase was positive is that it reduces the negative effect of shame. The consumers receiving social support may repeat impulse buying. However, the ones who are in mental disengagement do not repeat such behavior ( $\mathrm{Lu}$ et al. 2012). The results of the two models are consistent with the relevant studies (Lazarus and Folkman, 1984; Rook 1987; Strutton and Lumpkin, 1994; Jorgensen, 1996; Tangney et al. 1996; Zaltman, 1997; Barsky and Nash, 2002; Dahl et al. 2003; Venkatesh et al. 2003; Mattsson, 2004; Yi and Baumgartner, 2004-2011; Zeelenberg and Pieters, 2004; Allen et al. 2005; Laros and Stennkamp, 2005; Cheabat, 2005; Maclnnis and Patrick, 2006; Matilla and Ro, 2008; Beaudry and Pinsonneault, 2010; Dedeoğlu and Kazançoğlu, 2010-2012; Yi 2012; Yi and Kanetkar, 2012; Lu et al, 2012).

Guilt and shame were compared in terms of impulse buying and the intention to buy again. It was seen that the consumers felt much guiltier after impulse buying, which is also consistent with the literature (Yi and Baumgartner, 2011; 465). It was determined that shame was more influential on intention to repurchase as it is a strong feeling and has worse results. This situation is also stated in the literature, and it is claimed that as the severity of consumers' negative feelings increases, their intentions to buy again decrease (Jorgensen, 1996).

\section{LIMITATIONS AND RECOMMENDATIONS}

The present study focused on the difference between the direct and indirect effects of negative consciousness feelings and coping strategies on the intention to repurchase. It was found that the feelings of guilt and shame were experienced in different processes and brought about different results. The place of negative consciousness feelings in different consumption behaviors was explained by limiting the feelings of guilt and shame to impulse buying. It was indicated that the feelings experienced in different consumption behaviors and their reflections on the behavior would differ. The present study offers various recommendations for enterprises. Enterprises may use the feeling of guilt in ads as an instrument to influence consumers to buy their products. When a consumer likes the advertiser and the product that is advertised, he/she may develop positive feelings about it and buy the product again. Enterprises may use social networking sites to reduce the effects of shame and may be helpful in meeting the needs of customers for social support by intervening in the environments where consumers interact intensively. They may also provide consumers with different solutions such as refunding their money and taking the product back to help them cope with the negative feelings after purchase. Guilt and shame may also be used as a market segmentation instrument, and the target markets may be divided for those who feel shame and guilt separately. It is expected that the present 
study will guide future studies. The feelings of shame and guilt may bring about different results in different cultures, personalities, and product groups. For this reason, similar studies may be carried out with different product groups, in different regions, and with consumers having different personal characteristics. Research may be conducted to determine whether or not there is a difference between online and traditional purchases in terms of negative consciousness feelings; seek for variety; and the feelings of shame and guilt felt after experiential purchases such as hedonic purchases and obsessive purchases. The effects of coping strategies and feelings on different post-purchase consumer behaviors such as word of mouth communication, the intention to exchange an item, consumer loyalty, and the complaint behavior as well as on the intention to repurchase may be explored. Coping strategies may be evaluated taking into account different categories such as primary emotions, basic emotions, and set of different emotions. Whether or not consumers experience these feelings even after planned purchases may be investigated. It is also worth studying whether or not the feelings of guilt and shame are related to ambivalence and whether or not coping strategies vary in terms of this ambivalence. Whether or not different strategies are used in coping with these feelings and to what extent their use in ads can prevent negative purchases may be searched. Also, whether or not there is a relationship between sustainable consumption and social responsibility guilt may be investigated based on the idea that the individuals who do not achieve a sustainable consumption may feel social responsibility guilt more. One of the limitations of the present study is that it was carried out only in Istanbul and on young people. The feelings that consumers experience after impulse buying, their strategies to cope with these feelings, and the effects of coping strategies on the intention to repurchase was handled in terms of their general shopping behaviors. Another limitation of the study is that the results were not evaluated in terms of a specific brand or product groups. 


\section{REFERENCES}

Aaker, D. A., Stayman, D. M., and Vezina, R. (1988). “Identifying Feelings Elicited By Advertising”. Psychology and Marketing, 5(1), pp. 1-16.

Allen, C.T., Machleit, K.A., Kleine, S.S., ve Notani, A.S. (2005). “A Place For Emotion in Attitude Models”. Journal of Business Research, 58(4), pp. 494-499.

Aren, S. and Aydemir, S.D. (2014), "Some Considerations on Emotional Intelligence”, Journal of Global Strategic Management, 8(1), pp. 49-56.

Batra, R., and Holbrook, M. B. (1990). "Developing A Typology of Affective Responses to Advertising”. Psychology \& Marketing, 7(1), pp. 11-25.

Beaudry, A. ve Pinsonneault, A. (2010). "The Other Side of Acceptance: Studying The Direct and Indirect Effects of Emotions on Information Technology Use,” MIS Quarterly, 344: pp. 689-710.

Cheabat, J.C., Davidow, M., ve Codjovi, I. (2005). "Silent Voices: Why Some Dissatisfied Consumers Fail to Complain”. Journal of Service Research, 7(4), pp. 328-342.

Cohen, S., and Wills, T. A. (1985). "Stress, Social Support, and The Buffering Hypothesis”. Psychological Bulletin, 98(2), pp. 310-357.

Dahl, D. W., Honea, H., ve Manchanda, R. V. (2003). “The Nature of Self-Reported Guilt in Consumption Contexts”. Marketing Letters, 14(3), pp. 159-171.

Dedeoğlu, A.Ö., ve Kazançoğlu, İ. (2010). "The Feelings of Consumer Guilt: A Phenomenological Exploration”. Journal of Business, Economics and Management, 11(3), pp. 462-482.

Dedeoğlu, A.Ö., ve Kazançoğlu, I. (2012). "Consumer Guilt: A Model of Its Antecedents and Consequences”. Ege Akademic Review, 12(1), pp. 9-22.

Duhachek, A. (2004). An Investigation in to Consumer Coping Processes (A Dissertation). Northwestern University: Doctor of Philosophy, Field of Marketing.

Duhachek, A. (2005). "Coping: A Multidimensional, Hierarchical Framework of Responses to Stressful Con $\neg$ sumption Episodes”. Journal of Consumer Research, 32(1), pp. 41-53.

Edell, J.A., and Burke, M.C. (1987). “The Power of Feelings in Understanding Advertising Effects”. Journal of Consumer Research, 14, pp. 421-433.

Ekman, P. (1999). Basic Emotions. Handbook of Cognition and Emotion, T. Dalgleish and T. Power.

Folkman, S., Lazarus, R. S., Gruen, R. J., and DeLongis, A. (1986), “Appraisal, Coping, Health Status and Psychological Symptoms”. Journal of Personality and Social Psychology, 50(3), pp. 571-579.

Frijda, N.H., Kuipers, P., and Terschure, E. (1989). "Relations Among Emotion, Appraisal and Emotional Action Readiness”. Journal of Personality and Social Psychology, 57(2), pp. 212-228.

Ha, Y. and Lennon, S.J. (2010). "Effects of Site Design on Consumer Emotions: Role of Product Involvement”. Journal of Research In Interactive Marketing, 4(2), pp. 80-96.

Jorgensen, B.K. (1996). Components of Consumer Reaction to Company-Related Mishaps: a Structural Equation Model Approach, in NA - Advances in Consumer Research Volume 23, eds. Kim P. Corfman and John G. Lynch Jr., Provo, UT : Association for Consumer Research, Pages: pp. 346-351.

Jun, S., and Yeo, J. (2012). “Coping with Negative Emotions from Buying Mobile Phones: A Study of Korean Consumers". Journal of Family and Economic İssues, 33(2), pp. 167-176.

Laros, F. J. M., and Steenkamp, J. E. M. (2005). “Emotion in Consumer Behavior: A Hierarchical Approach”. Journal of Business Research, 58(10), pp. 1437-1445.

Ladhari, R., Brun, I., and Morales, M. (2008). "Determinants of Dining Satisfaction and Post-Dining Behavioral Intentions”. International Journal of Hospitality Management, 27 (4), pp. 563-573.

Lazarus, R. S., and Folkman, S. (1984). Stress, Appraisal, and Coping. New York: Springer 
Lazarus, R.S. (1993). “Coping Theory And Research: Past, Present, And Future”. Psychosomatic Medicine, 55, pp. 234-247.

Lewis, H. (1971). Shame and Guilt in Neurosis. New York: International University Press.

Lozinski, E,J., (2011). Coping with Shame And Guilt Following Diet Violation in Restrained Eaters (A Dissertation). The University of Guelph.

Lu, Y., Lu, Y., and Wang, B.(2012). "Effects of Dissatisfaction on Customer Repurchase Decisions in ECommerce-An Emotion-Based Perspective”. Journal of Electronic Commerce Research, 13(3), 224-237.

Maclnnis, D.J., and Patrick, V.M.(2006). "Spotlight on Affect: Affect and Affective Forecasting in Impulse Cont-rol”.Journal of Consumer Psychology,16(3), pp. 224-231.

Marschall, D. Saftner, J., and Tangney, J. P. (1994). The State Shame and Guilt Scale. George Mason University, Fairfax, VA.

Marschall, D. E (1996). Effects of Induced Shame on Subsequent Empathy and Altruistic Behavior Unpublished Master's Thesis, George Mason University, Fairfax, VA.

Mattila, A.S., and Ro, H. (2008). "Discrete Negative Emotions and Customer Dissatisfaction Responses in a Casual Restaurant Setting”. Journal of Hospitality \& Tourism Research, 32(1), pp. 89-107.

Menon, K., and Dube, L. (2004). "Service Provider Responses to Anxious and Angry Customers: Different Challenges, Different Payoffs”. Journal of Retailing, 80(3), pp. 229-237.

Parasuraman A. (2005). "ES-QUAL: A Multiple-item Scale for Assessing Electronic Service Quality”, Journal of Service Research, 7(3), pp. 213-233.

Pavlou, P. A., and M. Fygenson. (2006). "Understanding and Predicting Electronic Eommerce Adoption,” Management Information Systems Quarterly, 30(1), pp. 115-143

Plutchik, R. (1980). Emotion: A Psycho Evolutionary Synthesis, New York

Pounders, K. (2011). The Good, The Bad and The Unintended: The Role of Negative Self-Conscious

Emotions in Marketing, The Interdepartmental Program in Business Administration (Marketing) A

Dissertation, Louisiana State University.

Rook, D. W., and Hoch, S. J. (1985). “Consuming Impulses”. Advances in Consumer Research, 12(1), pp. 23-27.

Rook, D. W. (1987).“The Buying Impulse”.Journal of Consumer Research, 14(2), pp. 189-199.

Rook, D.W., and Fisher, R.J. (1995). “Normative Influences on Impulsive Buying Behavior”. Journal of Consumer Research, 22(3), pp. 305-313.

Russell, J.A., and Mehrabian, A. (1977). “Evidence for A Three-Factor Theory of Emotions”. Journal of Research in Personality, 11(3), pp. 273-294.

Stevens, M. (1998). Problem Analysis, Istanbul: Timas Publishing, 1st edition.

Strutton, D., and Lumpkin, J.R.(1994). "Problem and Emotion-Focused Coping Dimensions and Sales Presentation Effectiveness”. Journal of the Academy of Marketing Science, 22(1), pp. 28-37.

Şahin, A., Zehir, C., and Kitapçı, H. (2012). "The Effects of Brand Experience and Service Quality on Repurchase Intention: The Role of Brand Relationship Quality”, African Journal of Business Management Vol.6 (45), pp. 11190-11201

Tam, L., and Dholakia, U. M. (2008). “The Effects of Time Frames on Personal Savings Estimates. Saving Behavior, and Financial Decision Making”, pp. 1-35.

Tangney, J. P., and Dearing, R. L. (2002). Shame \& Guilt. New York: Gilford Press.

Tangney, J.P., Stuewig, J., \&Mashek, D.J. (2007). “Moral Emotions and Moral Behaviour”, Annual Review Psychology, 57, pp. 345-72 
Journal of Global Strategic Management | V. 9 | N. 2 | 2015-December | isma.info | 119-133 | DOI: 10.20460/JGSM.2015915578

Tracy, J.L., Robins, R.W., and Tangney, J.P.(Eds.). (2007). The Self-Conscious Emotions: Theory And Research. Guilford Press.

Venkatesh, V., Morris, M.G., Davis, G. B., ve Davis, F. D. (2003). User Acceptance of İnformation Technology: Toward a Unified View. MIS Quarterly, pp. 425-478.

Yi, S., and Baumgartner, H. (2004). "Coping with Negative Emotions in Purchase-Related Situations”. Journal of Consumer Psychology, 14 (3), pp. 303-317.

Yi, S., and Kanetkar, V. (2011). “Coping with Guilt and Shame After Gambling Loss”. Journal of Gamble Study, 27, pp. 371-387.

Yi, S., and Baumgartner, H. (2011). “Coping With Guilt And Shame in The Impulse Buying Context”, Journal of Economic Psychology, 32, pp. 458-467.

Yi, S. (2012). "Shame-Proneness as A Risk Factor of Compulsive Buying”. Journal of Consumer Policy, 35(3), pp. 393-410.

Zaltman G. (1997). "Rethinking Market Research: Putting People Back in”. Journal of Marketing Research, 34, pp. 424- 437

Zeelenberg, M., ve Pieters, R. (2004).“Beyond Valence in Customer Dissatisfaction: A Review and New Findings on Behavioral Responses to Regret and Disappointment in Failed Services”. Journal of business Research,57(4), pp. 445-455.

Zeelenberg, M., ve Pieters, R. (2007). “A Theory of Regret Regulation 1.0”. Journal of Consumer Psychology, 17(1), pp. 3-18. 